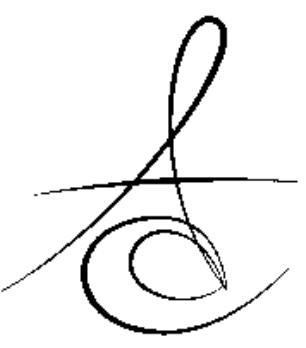

Prof. Dr. Muhammed Selim YAVUZ*

Dr. Dt. Zeynep SAVAŞ BAYRAMOĞLU**

\title{
A CONSERVATIVE SURGICAL APPROACH TO OSTEOCHONDROMA OF THE TEMPOROMANDIBULAR JOINT
}

\section{TEMPOROMANDİBULAR EKLEMİN OSTEOKONDROMASINA KONSERVATİF CERRAHİ YAKLAŞIM}

\author{
Prof. Dr. Nesrin GÜRSAN ${ }^{* * *}$
}

Makale Kodu/Article code: 2762

Makale Gönderilme tarihi: 02.04 .2016

Kabul Tarihi: 11.05.2016

\section{ÖZET}

Osteochondroma is an exophytic lesion that arises from the bone cortex and is capped with cartilage. Although osteochondromas are rare in the craniofacial area, the most affected areas are commonly coronoid process and condyle. The surgical treatment for an OC of the mandibular condyle has normally either been condylectomy or local excision with or without reconstruction.

This paper describes a case of osteochondroma of the mandibular condyle in a 48-year-old woman who was referred with facial asymmetry, deviation of chin, cross-bite to the contralateral side and malocclusion. Panoramic radiographs and computerized tomographic scans of the patient confirmed the presence of a bony expansion of the left condyle. Based on clinical and radiographic evaluations, the clinical diagnosis was made as osteochondroma. High condylectomy procedure was planned for reshaping condylar head without additional reconstructive surgery. Condylectomy was performed using a preauricular approach with total removal of the lesion under general anesthesia. The healing was uneventful, and the patient was satisfied with appearance and occlusion in two years.

Keywords: Osteochondroma; Temporomandibular Joint; Mandibular Condyle

\section{ABSTRACT}

Osteokondrom, kemik korteksinden büyüyen ve kartilajla kaplı ekzofitik bir lezyondur. Kraniofasial bölgede nadir görülmesine rağmen en çok etkilenen alanlar koronoid proses ve kondildir. Mandibular kondilde görülen osteokondromların cerrahi tedavisi, lezyonun rekonstrüksiyonla birlikte veya rekonstrüksiyon yapılmadan kondilektomi veya lokal eksizyonudur.

$\mathrm{Bu}$ raporda yüzde asimetri, çene ucu deviasyonu, karşı tarafta dişlerin çapraz kapanışı ve maloklüzyona neden olmuş osteokondrom belirtileriyle başvuran 48 yaşındaki kadın hastanın tedavisi ve 2 yıllık takip sonuçları bildirilmektedir. Alınan panoramik radyografi ve bilgisayarlı tomografi görüntüleriyle sol kondildeki kemik ekspansiyonu doğrulandı. Klinik ve radyografik değerlendirmelere dayanarak klinik tanı osteokondrom olarak belirlendi. İlave rekonstrüktif cerrahi olmaksızın kondil başının yeniden şekillendirilmesi için yüksek seviyeli kondilektomi planlandı. Genel anestezi altında preaurikular yaklaşımla lezyon bütünüyle çıkarılarak kondilektomi yapıldı. Sorunsuz iyileşme gözlenirken 2 yıl sonunda hastanın mevcut oklüzyon ve görünümden memnun olduğu görüldü.

Anahtar Kelimeler: Osteokondrom; temporomandibüler eklem; mandibular kondil

\footnotetext{
${ }^{*}$ Serbest Diş hekimi.

${ }^{* *}$ In private practice

${ }^{* * *}$ Professor, Atatürk University, Faculty of Medicine, Department of Pathology
} 


\section{INTRODUCTION}

Osteochondroma (OC) also known as osteocartiloginous exostosis is one of the most common benign tumors of the long bones. OCs of the facial skeleton develop from bones growing by endochondral ossification, thus these lesions involve condyle, coronoid, symphysis of the mandibula, zygoma, zygomatic arch and nasal septum at the facial skeleton ${ }^{1}$.

Generally OC affects females around forty years-age. Pathogenesis of OC whether it is developmental or neoplastic is controversial. A relatively high frequency of $O C$ around the temporomandibular joint (TMJ) can be explained with persistence of embryonic remnants in this area 2.

Etiology of the lesion is still controversial; hence different etiologies have been hypothesized. Nests of chondrocytes in periosteum and mechanical stress to chondrocytes were claimed as an etiologic factor because of the localizations of lesion ${ }^{3,4}$.

Saito et al. reported that traumatic factors such as temporomandibular disorders may cause the osteochondroma in the mandibular condyle ${ }^{5}$. Trauma and inflammation have been suggested as contributory factors of the condylar osteochondroma by Seki et al ${ }^{6}$. Porter and Simpson suggested genetic component might also be involved in pathogens is due to mutations in chromosomes 8 and $11^{7}$.

The most common symptom of OC of condyle is deviation of midline to unaffected side, cross-bite on the contralateral side and mild pain ${ }^{2,8}$. The tumor easily diagnosed with computerized tomography (CT) or panoramic radiographs because they give typical radiographic image. CT scans indicate bone growth outwardly with continuation of cortex and medulla ${ }^{9}$.

The surgical treatments of the osteochondroma of condyle are condylectomy or local excision ${ }^{2}$. The recommended treatment for $\mathrm{OC}$ of the condyle is resection of the lesion with the maximum protection of the condylar head ${ }^{8,10}$.

\section{CASE REPORT}

A 46-year-old woman presented in 2012 with complaints of progressive malocclusion, left TMJ pain and history of right-side deviation of the mandibular midline. Clinical examination showed an acceptable but asymmetric jaw opening with mandibular deviation of the midline. The patient had a cross-bite in the right side (Figure 1). There was no irregular structure of the condyles in bilateral palpation. Lateral temporomandibular radiography showed a mass extending on the medial surface and limited movement of the left condyle (Figure 2). Tomographic scans showed a bony expansion of the left condyle (Figure 3). Based on these symptoms, the clinical diagnosis was made as $\mathrm{OC}$ of the condyle. The patient was using bridge prosthesis made according to the malocclusion. The patient asked us whether we solve the current problems or not with surgery. We recommended the surgical excision of the lesion without reconstruction to be solving the problems, and she accepted the surgical intervention. The operation was performed under general anesthesia through a nasoendotracheal intubation with preauricular approach. The high condylectomy procedure was performed with presserving condyle and articular disc. The tumor was resected from healthy bone in a manner new condyle (Figure 4). Histopathologic examination of the osteochondroma showed a bone trabeculation covered by a cartilage cap with underlying fibrous connective tissue (Figure 5).

The healing was uneventful. Posterior bridges of the patient renewed in terms of normal occlusion. Two years later, the patient has excellent functional, occlusal and facial esthetic without additional surgery or orthodontics (Figure 6). Postoperative panoramic and temporomandibular radiographs showed an excellent remodeling and function of the operated condyle (Figure 7 and 8).

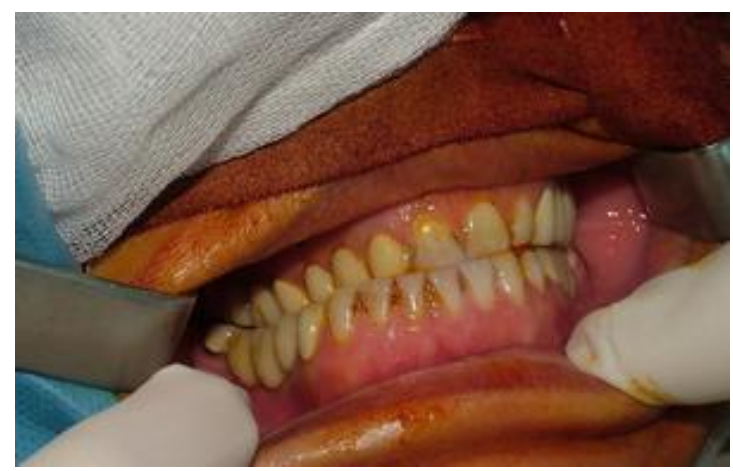

Figure 1. Preoperative occlusion assessment. Deviation of chin, cross-bite to the contralateral side (right) and

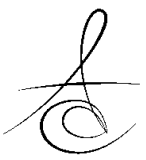


Atatürk Üniv. Diş Hek. Fak. Derg.

J Dent Fac Atatürk Uni

Supplement: 16, Yıl: 2016, Sayfa : 18-22

malocclusion were seen.

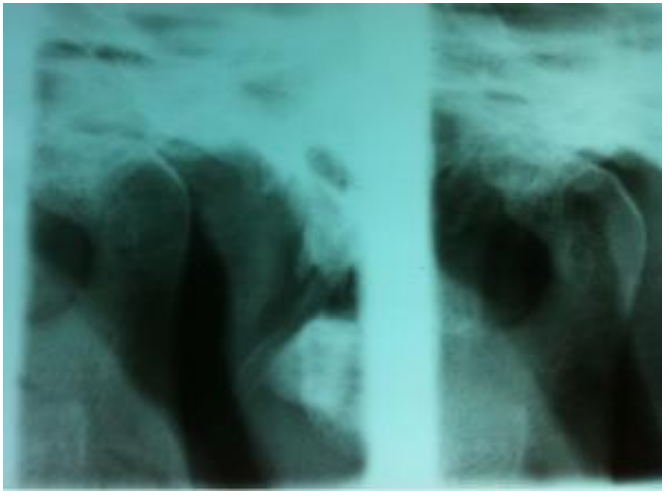

Figure 2. Temporomandibular joint radiograph showed a mass extending on the medial surface of the left condyle.

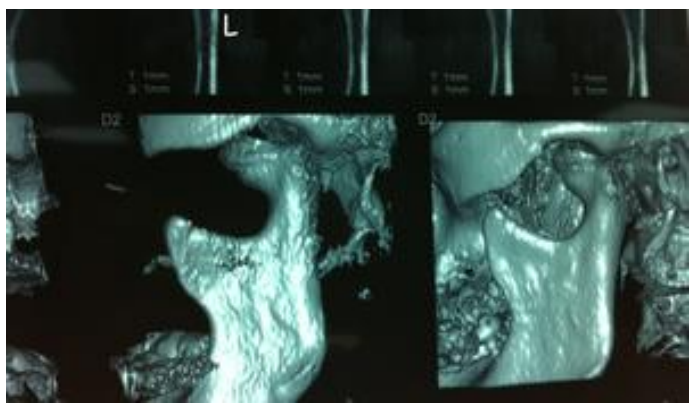

Figure 3. Preoperative computerized tomography scans.

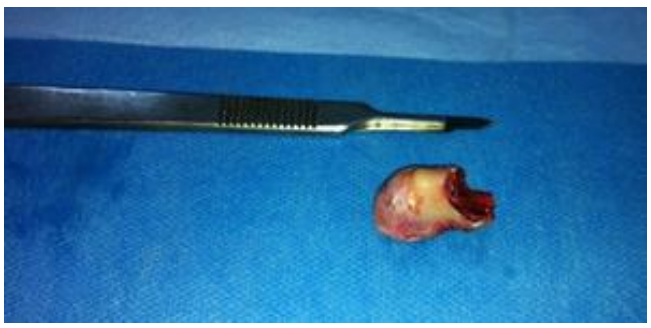

Figure 4. The tumor was resected from healthy bone in a manner new condyle.

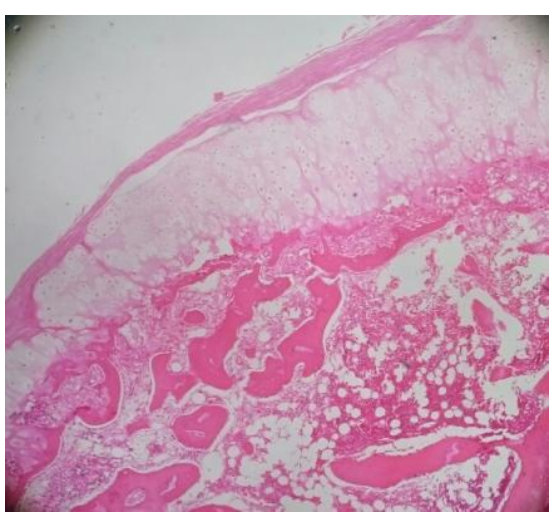

YAVUZ, BÜYÜKKURT, BAYRAMOĞLU, VELİOĞLU

GÜRSAN

Figure 5. Hematoxylin and eosin (H\&E) staining of the tumor sections (magnification $40 x$ ).

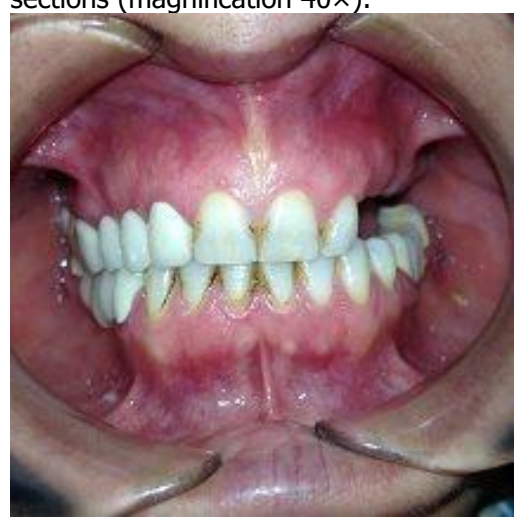

Figure 6. Two years later, the patient has excellent functional, occlusal and facial balance without additional surgery or orthodontics.

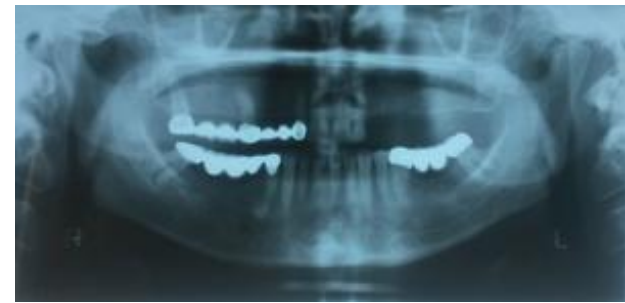

Figure 7. Postoperative panoramic radiograph.

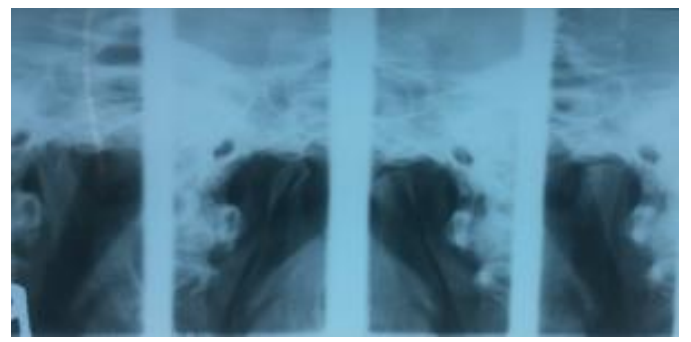

Figure 8: Postoperative temporomandibular radiographs.

\section{DISCUSSION}

OC of the mandibular condyle is quite rare. Because they arise only from endochondral bones, usually encountered in long bones. Some authors claim that the lesion is usually seen sixth decade, the others claim that patients are usually young 2,11 . There was no gender predilection. Facial asymmetry, deviation of the chin midpoint to the unaffected side and malocclusion with open bite are typical symptoms in patients with the TMJ osteochondroma ${ }^{2,11}$. In differential diagnosis of the osteochondroma of the

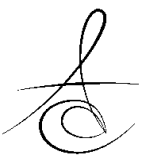


TMJ, hemifacial hypertrophy, synovial chondromatosis, osteoblastoma and ossifying fibroma of the condyle should be ruled out. However the radiographic appearance as a medial condylar mass together with clinical symptoms of an ostechondroma is distinctive.

$\mathrm{OC}$ of the condyle requires local excision. Some authors suggest that OC of the condylar head can be treated with local resection such as high level condylectomy with recontouring as in our case $8,12,13,14$. This more conservative approach focuses the exophytic nature of the lesion, and eliminates additional reconstructive surgery with preserving remaining bone ${ }^{2,12}$. Some surgeons prefer additional reconstructive surgery such as a vertical ramus osteotomy with superiorly advancement of the condylar segment to be satisfactory TMJ function ${ }^{15,16}$.

Removal is indicated if the tumor is displeasing, is producing pain or discomfort, has radiological features suggestive of malignancy, or shows an abnormal increase in size ${ }^{17}$.

Condylectomy was performed by Humpfrey firstly in 1854, and with the evolution of technique most authors agreed on the importance of reconstruction of the condylar head after surgery. The main purpose in high level condylectomy is to create a new joint surface as similar as possible to the original during the surgery. Therefore, vertical dimension of the ramus and occlusion should not change too much to be preserving the mechanics of the mandible.

Complications of condylectomy procedure are open bite, chin deviation to operated side, TMJ ankylosis, disfunction and difficulty to make the lateral movements due to failure of reattachment of lateral pterygoid muscle to operated condyle ${ }^{18}$.

Many authors indicate that high condylectomy procedure is an effective surgical technique in treatment of long standing degenerative TMJ disorders. ${ }^{19,21}$

Alexandridis et al investigate in response to functional stress of new condylar surfaces after bilateral high condylectomy in photoelastic human mandible model, and they emphasized the new condylar surfaces present similar functional and stress distribution properties with normal condyles. However the functional properties of photoelastic mandibles undergone unilateral condylectomy were different from normal condyles ${ }^{22}$.
Alexandridis et al mentioned if the condylectomy is performed in a higher level in OC of the condyle the level of asymmetry can be decreased and more ideal functional forces might be hope. Conversely if the condylectomy is performed on the condylar neck, asymmetry and failure of occlusion will occur. In these cases, a condylar reconstruction procedure is mandatory to mandibular balance and function ${ }^{22}$.

When head and neck of the condyle are affected from the OC, comprehensive surgical interventions should take into consideration, such as condylectomy and temporomandibular joint reconstruction $2,10,13$.

Recently, costochondral grafts and total joint prosthesis are the most commonly used materials for simultaneous TMJ reconstruction methods. Donor site morbidity and unpredictable graft resorption are the disadvantages of costochondral grafts. High costs of device, material wear, potential failure and restricted use in growing patients are the disadvantages of total joint prosthesis. At the same time, long-term results of TMJ prosthesis is not clear ${ }^{2}$.

We recommend the high condylectomy with preserving articular disc and resecting in a manner condylar head, if there is existence of unaffected condylar part. We think that this technique is superior to complicated reconstructive and orthognathic approach in most TMJ osteochondroma cases.

\section{REFERENCES}

1. Baniwal S, Meru S, Biswas B. Osteochondroma of the glenoid fossa-A case report. $\mathrm{Br} J$ Oral Maxillofac Surg 2007; 45: 579-81.

2. Ramos-Murguialday M, Morey-Mas MÁ, JaneiroBarrera S, García-Sánchez A, Molina-Barraguer I, Iriarte-Ortabe JI. Osteochondroma of the temporomandibular joint: Report of 2 cases emphasizing the importance of personalizing the surgical treatment. Oral Surg Oral Med Oral Pathol Oral Radiol 2012;113:41-7.

3. Ribas Mde O, Martins WD, de Sousa MH, Zanferrari $\mathrm{FL}$, Lanzoni T. Osteochondroma of the mandibular condyle: Literature review and report of a case. J Contemp Dent Pract 2007; 8: 52-9.

4. González-Otero S, Navarro-Cuéllar C, Escrig-de Teigeiro M, Fernández-Alba-Luengo J, Navarro-Vila 
C. Osteochondroma of the mandibular condyle: Resection and reconstruction using vertical sliding osteotomy of the mandibular ramus. Med Oral Patol Oral Cir Bucal. 2009 Apr 1;14: 194-7.

5. Saito $T$, Utsunomiya $T$, Furutani $M$, Yamamoto $H$. Osteochondroma of the mandibular condyle: $A$ case report and review of the literature. J Oral Sci 2001;43: 293-7.

6. Seki H, Fukuda M, Takahashi T, Iino M. Condylar osteochondroma with complete hearing loss: Report of a case. J Oral Maxillofac Surg 2003; 61: 131-3.

7. Porter DE, Simpson AH. The neoplastic pathogenesis of solitary and multiple osteochondromas. J Pathol 1999;188: 119-25.

8. Yu HB, Sun H, Li B, Zhao ZL, Zhang L, Shen SG, Wang XD. Endoscope-assisted conservative condylectomy in the treatment of condylar osteochondroma through an intraoral approach. Int J Oral Maxillofac Surg. 2013; 42: 1582- 6.

9. Roychoudhury A, Bhatt K, Yadav R, Bhutia O, Roychoudhury S. Review of osteochondroma of mandibular condyle and report of a case series. J Oral Maxillofac Surg. 2011 Nov; 69:2815-23

10. Karras SC, Wolford LM, Cottrell DA. Concurrent osterchondroma of the mandible condyle and ipsilateral cranial base resulting in TMJ ankylosis. Report of a case and review of the literature. J Oral Maxillofac Surg. 1996;54: 640-6.

11. Marx RE, Stern D: Oral and Maxillofacial Pathology. A rationale for diagnosis and treatment, 2nd edition. Chicago: Quintessence Publishing, 2012; $p$ 822-5.

12. Cottrell D, Mehra P, Franco P. Discussion-Use of conservative condylectomy for treatment of osteochondroma of the mandibular condyle. J Oral Maxillofac Surg 2002; 60: 262-8.

13. Wolford LM, Mehra P, Franco P. Use of conservative condylectomy for treatment of osteochondroma of the mandibular condyle. J Oral Maxillofac Surg 2002; 60: 262-8.

14. Aydin MA, Küçükçelebi $A$, Sayilkan $S$, Celebioğlu S. Osteochondroma of the mandibular condyle: report of 2 cases treated with conservative surgery. J Oral Maxillofac Surg. 2001; 59: 1082-9.
15. Holmund AB, Gynther GW, Reinholt FP. Surgical treatment of osteochondroma of the mandibular condyle in the adult. A 5-year follow-up. Int J Oral Maxillofac Surg 2004; 33: 549-53.

16. Loftus MJ, Bennett JA, Fantasia JE. Osteochondroma of the mandibular condyle. Report of three cases and review of the literature. Oral Surg Oral Med Oral Pathol Oral Radiol Endod 1986; 61: 221-6.

17. Akal Ü, Or S, Nalçacı R, Orhan K, Günhan Ö. Mandibulada Osteokondroma (Kartilajinöz Ekzostoz): Bir Olgu Bildirimi. Turkiye Klinikleri J Dental Sci 2000;6:163-7

18. Giray B, Aktaş B, Öktemer B, Taner T, Akcan C, Meral G, Ökten S. Yetişkin Hastada Kondiler Hiperplazi. Hacettepe Diş Hekimliği Fakültesi Dergis, 2008; 32: 45-50.

19. Baldridge OL, Henny FA. Condylectomy for the persistently painful temporomandibular joint. J Oral Surg 1957; 15: 24-31.

20. Henny FA. Surgical treatment of the painful temporomandibular joint. J Am Dent Assoc 1969; 79: 171-7.

21. Cherry CQ, Frew A Jr. High condylectomy for treatment of arthritis of the temporomandibular joint. J Oral Surg 1977; 35: 285-8.

22. Alexandridis C, Caputo AA, Eliades GC. Functional stress modification after high condylectomy surgery. J Oral Rehabil 1991; 18: 317-26.

\author{
Yazışma Adresi \\ Özlem Velioğlu \\ Osmangazi mah. 592. Sok. \\ Bayraklı- Izmir/ Turkey \\ TIf: $\quad 905312196239$ \\ e-mail: ozlemkadr@gmail.com
}

